\title{
Peran Guru Menciptakan Disiplin Kelas Terhadap Peningkatan Prestasi Belajar Siswa MI Muhammadiyah 11 Blimbing Paciran Lamongan
}

\author{
Zainal Mahfud \\ Sekolah Tinggi Ilmu Tarbiyah Muhammadiyah Paciran Lamongan \\ Email:zainal84@yahoo.co.id
}

\begin{abstract}
The research focus discussed in this thesis is (1) How is the role of teacher in creating classroom discipline in MI Muhammadiyah 11 Blimbing Paciran Lamongan, (2) How is student achievement in MI Muhammadiyah 11 Blimbing Paciran Lamongan, (3) Is there any correlation between role teachers in creating classroom discipline with student achievement in MI Muhammadiyah 11 Blimbing Paciran Lamongan. This research uses the following methods: population, sample, data source, data collection method and also data analysis technique. In this research, it can be concluded that there are four roles that must be done by a teacher in creating classroom discipline, that is teacher as first implementer of discipline, teacher as student director in carrying out all school rules, teacher as supervisor in implementing all school rules and teacher giving gifts and punishments to the students. Student achievement of MI Muhammadiyah 11 Blimbing Paciran Lamongan in academic year 2014/2015 shows enough value.

There is a correlation between the role of teachers in creating classroom discipline to improve student achievement in MI Muhammadiyah 11 TPAY Blimbing Paciran Lamongan and the correlation shown is quite correlation with score value of 0.698 .
\end{abstract}

Key word: Teacher's Role, Class Discipline, and Student Learning Achievement

Pendidikan yang berlangsung sekarang ini merupakan pendidikan masa lalu yang mengalami perubahan dan penyempurnaan. Hal ini disebabkan karena adanya pengaruh ilmu pengetahuan dan teknologi yang berkembang dewasa ini. Dengan perkembangan ilmu pengetahuan dan teknologi semua aspek kehidupan manusia dapat dipengaruhinya, termasuk di bidang pendidikan. Perubahan dan penyempurnaan ini terjadi secara menyeluruh baik teori maupun prakteknya serta termasuk pengertian pendidikan itu sendiri.

Hal tersebut di atas kemudian berimbas dengan munculnya tantangantantangan peningkatan mutu, relevansi, dan efektivitas pendidikan sebagai tuntutan nasional sejalan dengan perkembangan dan kemajuan masyarakat, berimplikasi secara nyata dalam program pendidikan dan kurikulum sekolah. Tujuan dari program kurikulum dapat tercapai dengan baik jika programnya didesain secara jelas dan aplikatif. (Moh. Uzer Usman, 2001, p.5)

Dilihat dari sisi aktualisasinya, pendidikan merupakan proses interaksi antara guru (pendidik) dengan peserta didik (siswa) untuk mencapai tujuan-tujuan pendidikan yang ditentukan. Pendidik, peserta didik, dan tujuan pendidikan merupakan komponen utama pendidikan. Ketiganya membentuk suatu triangle, 
yang jika hilang salah satunya, maka hilang pulalah hakikat pendidikan. (Abidin Nata, 2003, p.134)

Berangkat dari pemahaman asumsi di atas, maka guru merupakan salah satu faktor penentu keberhasilan setiap upaya pendidikan. Itulah sebabnya setiap adanya inovasi pendidikan, khususnya dalam kurikulum dan peningkatan sumber daya manusia yang dihasilkan dari upaya pendidikan selalu bermuara pada faktor guru. Hal ini menunjukkan bahwa betapa eksisnya peran guru dalam dunia pendidikan, orang jawa memiliki pepatah "guru iku digugu lan ditiru".

Berdasarkan posisi dan tanggung jawab tersebut, maka guru tidak hanya dituntut untuk memiliki standar pengetahuan, ketrampilan, sikap, dan nilai saja, melainkan juga harus memiliki tingkat derajat kepercayaan yang tinggi di mata siswa-siwanya. Disamping itu, guru juga harus dapat memberikan tauladan yang baik bagi siswa-siswanya, karena apa yang menjadi tingkah laku guru akan menjadi panutan siswa-siswanya.( Ahmad D Marimba, 1981, p.37-40)

Sejalan dengan itu Moh. Uzer Usman menyatakan bahwa guru merupakan faktor yang dominan dan paling penting dalam pendidikan formal pada umumnya karena guru bagi siswa sering dijadikan tauladan, atau bahkan menjadi identifikasi diri. (Moh. Uzer Usman, 2001, p.6-8) Oleh sebab itu, guru seyogyanya memiiki kemampuan yang memadai untuk mengembangkan siswanya secara utuh dan dapat melaksanakan tugasnya secara baik sesuai dengan profesi yang dimilikinya.

Dalam UU SISDIKNAS No 20 Tahun 2003 Pasal 3 dinyatakan bahwa "pendidikan nasional bertujuan untuk berkembangnya potensi peserta didik agar menjadi manusia yang beriman dan bertqwa kepada Tuhan Yang Maha Esa, berakhlaq mulia, sehat, berilmu, cakap, kreatif, mandiri, dan menjadi warga yang demokratis, bertanggung jawab, produktif serta sehat jasmani dan rohani". (Undang-Undang Republik Indonesia Nomor 20 Tahun 2003 Tentang Sistem Pendidikan Nasional, 2003, p.3)

Dari dasar tujuan pendidikan nasional di atas, maka jelaslah bahwa untuk mewujudkan tujuan pendidikan nasional dibutuhkan guru, peserta didik, serta masyarakat yang berkualitas. Dalam arti manusia yang beriman kepada Tuhan Yang Maha Esa, berkepribadian baik, disiplin, mandiri, berkembang, tangguh, cerdas, kreatif, terampil, demokratis, tanggung jawab, produktif, serta sehat jasmani dan rohani.

Pendidikan nasional membutuhkan manusia yang disiplin, manusia yang dimaksud adalah guru, siswa, dan masyarakat. Oleh karena itu, kedisiplinan dalam dunia pendidikan sangat diperlukan bahkan merupakan suatu kewajiban yang harus dilaksanakan terutama sebagai guru.

Masalah disiplin merupakan masalah yang sangat berat bagi seorang guru, sebab berhasilnya seorang guru dalam mendidik tergantung pada kemampuannya dalam menciptakan disiplin kelas. Guru yang mampu memelihara disiplin kelas, maka dia akan berhasil dalam mendidik siswa-siswinya. Namun kebalikannya, apabila ada seorang guru tidak mampu memelihara disiplin kelas maka ia tidak akan berhasil dalam mendidik siswa-siswinya.

Berdasarkan permasalahan diatas, maka penulis ingin mengkajinya dengan judul penelitian "Peranan Guru dalam Menciptakan Disiplin Kelas terhadap 
Peningkatan Prestasi Belajar Siswa di MI Muhammadiyah 11 Blimbing Paciran Lamongan".

Berdasarkan latar belakang masalah di atas, maka rumusan rumusan masalah sebagai berikut: Bagaimana peranan guru dalam menciptakan disiplin kelas di MIM 11 Blimbing Paciran Lamongan, dan Bagaimana prestasi belajar siswa di MIM 11 Blimbing Paciran Lamongan?

\section{KAJIAN TEORI}

\section{Pengertian Guru}

Istilah guru amatlah luas pengertiannya. Untuk mempermudah pemahaman tentang pengertian guru, maka penulis jelaskan bahwa yang dimaksud guru dalam skripsi ini adalah guru sebagai pendidik formal.

Dalam hal ini, banyak ahli pendidikan yang mendefinisikan tentang pengertian guru, antara lain;

\section{a. Menurut Ngalim Purwanto}

"Guru adalah semua orang yang pernah memberikan suatu ilmu atau kepandaian tertentu kepada seseorang atau sekelompok orang". (Ngalim Purwanto, 1995, p.138)

\section{b. Menurut Amir Daien Indrakusuma}

"Guru adalah pihak atau subyek yang melaksanakan pekerjaan mendidik dan secara langsung berhadapan dengan peserta didik".(Amir Daien Indrakusuma, 1973, p.177)

\section{c. Menurut Hamdani Ihsan dan A. Fuad Ihsan}

"Guru adalah orang dewasa yang bertanggung jawab memberi bimbingan atau bantuan kepada anak didik (para murid) dalam perkembangan jasmani dan rohaninya agar mencapai kedewasaanya, mampu melaksanakan tugasnya sebagai makhluk Allah, khalifah di permukaan bumi, sebagai makhluk sosial, dan sebagai individu yang sanggup berdiri sendiri”.(Ihsan, Hamdani -A. Fuad Hasan, 1998, p.93)

\section{d. Menurut UU Guru Dan Dosen No 14 Tahun 2005}

"Guru adalah pendidik profesional dengan tugas utama mendidik, mengajar, membimbing, mengarahkan, melatih, menilai, dan mengevaluasi peserta didik pada pendidikan anak usia dini jalur pendidikan formal, pendidikan dasar, dan pendidikan menengah. (Undang-Undang Guru dan Dosen nomor 14 tahun 2005)

Dari beberapa uraian di atas, maka guru dapat didefinisikan sebagai orang yang sudah dewasa jasmani dan rohaninya dengan tugas utama mendidik, mengajar, membimbing, mengarahkan, melatih, menilai, dan mengevaluasi peserta didik pada pendidikan anak usia dini jalur pendidikan formal, pendidikan dasar, dan pendidikan menengah sehingga diharapkan bisa menjadi orang yang berguna bagi agama dan masyarakat.

\section{Syarat-Syarat Menjadi Guru}

Guru merupakan salah seorang yang dipercaya masyarakat untuk membantu dan mengajar serta mendidik anaknya. Agar tidak meruntuhkan kepercayaan masyarakat terhadap guru yang telah dipercaya dan diberi tanggung jawab dalam membantu mendidik anak-anaknya baik melalui lembaga formal 
maupun lembaga informal, maka seorang guru harus mempunyai beberapa persyaratan supaya berhasil dalam menjalankan tugasnya.

Menurut UU guru dan dosen No 14 tahun 2005, bahwa syarat-syarat menjadi guru adalah :

a. Kualifikasi akademik sarjana atau diploma (S1 atau D-IV)

b. Kompetensi pedagogik, kepribadian, sosial dan profesional

c. Sertifikat pendidik

d. Sehat jasmani dan rohani

e. Kemampuan mewujudkan tujuan pendidikan nasional.(Undang-Undang Guru dan Dosen nomor 14 tahun 2005)

Menurut H. Mubangit, untuk menjadi seorang guru haruslah mempunyai syarat-syarat sebagai berikut;

a. Dia harus beragama

b. Mampu bertanggung jawab atas kesejahteraan agama

c. Dia tidak kalah dengan guru sekolah umum lainnya dalam membentuk warga Negara yang demokratis dan bertanggung jawab atas kesejahteraan bangsa dan tanah air.

d. Dia harus memiliki perasaan panggilan murni (reoping).(Hamdani Ihsan, A. Fuad Hasan, 1998, p.102)

Selain itu, Abu Ahmadi dan Nur Uhbiyati juga mengatakan bahwa syaratsyarat menjadi guru itu meliputi;

\section{a. Umur}

Agar mampu menjalankan tugas mendidik, seorang guru seharusnya dewasa dulu. Batasan dewasa sangat relatif. Sesuai dengan segi peninjauannya. Menurut Negara kita, seorang dianggap dewasa setalah berumur 18 tahun atau sudah menikah. Menurut ilmu pendidikan, seseorang dikatakan dewasa untuk laki-laki bila sudah berumur 21 tahun dan 18 tahun untuk wanita.

\section{b. Kesehatan}

Seorang guru wajib sehat jasmani dan rohani, tidak berpenyakit menular dan membahayakan, serta tidak memiliki cacat tubuh yang bisa mengganggu dan menghambat kelancaran tugas mengajar di kelas.

\section{c. Keahlian atau Skill}

Syarat mutlak yang menjamin berhasil baik, baik bagi semua cabang pekerjaan adalah kecakapan atau keahlian pada para pelaksana itu. Proses pendidikanpun akan berhasil dengan baik bilamana para guru mempunyai keahlian, mempunyai skill, dan mempunyai kecakapan yang memenuhi persyaratan untuk melaksanakan tugas-tugasnya.

\section{d. Kesusilaan dan Dedikasi}

Seorang guru harus mempunyai kesusilaan atau budi pekerti yang baik dan mempunyai pengabdian yang tinggi, karena hal ini adalah sebagai konsekuensi dari rasa tanggung jawabnya agar mampu menjalankan tugasnya, mampu membimbing anak didik menjadi manusia susila serta menjadi manusia yang bermoral.(Ahmadi, Abu - Nur Uhbiyati, 2001, p. 243-246) 
Dari syarat-syarat tersebut di atas, dapat disimpulkan bahwa mengingat tugas sebagai guru adalah tugas berat tetapi mulia, maka dituntut syarat-syarat jasmani, rohani, dan yang lainnya yang diharapkan dapat menunjang untuk memikul tugas itu dengan sebaik-baiknya.

\section{Sifat-Sifat Seorang Guru}

Di muka telah dikatakan bahwa salah satu syarat yang harus dipenuhi oleh guru adalah berkelakuan baik, maka di dalamnya mengandung segala sifat, watak, dan sikap-sikap yang baik.

Menurut Ngalim Purwanto, bahwa sifat-sifat yang baik yang harus tercermin dalam sosok seorang guru diantaranya;

a. Guru harus adil

b. Guru harus percaya dan suka kepada muridnya

c. Guru harus sabar dan rela berkorban

d. Guru harus mempunyai kewibawaan terhadap siswa-siswanya

e. Guru bersikap baik terhadap guru-guru yang lain

f. Guru bersikap baik terhadap masyarakat

g. Guru harus menguasai benar-benar mata pelajarannya

h. Guru harus suka terhadap mata pelajaran yang diberikannya

i. Guru hendaknya berpengetahuan yang luas.(Ngalim Purwanto, 1995, p.143-148)

Sedangkan Abdurrahman An Nahlawi mengatakan bahwa sifat-sifat yang baik yang harus dimiliki oleh seorang guru antara lain;

a. Tingkah laku dan pola pikir guru harus bersifat mulia

b. Bersifat ihlas

c. Bersifat sabar

d. Bersifat jujur

e. Senantiasa membekali diri dengan ilmu dan kebiasaan untuk terus mengkajinya

f. Mampu menggunakan berbagai metode mengajar secara bervariasi, menguasainya dengan baik serta mampu menentukan dan memilih metode mengajar yang selaras bagi materi pengajaran serta situasi belajar mengajarnya.

g. Guru mampu mengelola siswa, tegas dalam bertindak serta meletakkan berbagai perkara secara proposional

h. Guru mempelajari kehidupan psikis para pelajar selaras dengan masa perkembangannya ketika ia mengajar mereka, sehingga dia dapat memperlakukan mereka sesuai dengan kemampuan akal dan kesiapan psikis mereka.

i. Guru tanggap terhadap berbagai kondisi dan perkembangan dunia yang memengaruhi jiwa, keyakinan, dan pola pikir angkatan muda. Disamping itu, hendaknya guru memahami pula berbagai problema kehidupan modern serta bagaimana cara menghadapi dan mengatasinya.

Dari uraian tersebut di atas dapat disimpulkan, bahwa sifat-sifat guru yang terpokok adalah ;

1. Guru harus berlaku adil, maksudnya guru harus beraku adil terhadap semua anak didiknya dan tidak pilih-pilih. 
2. Guru harus bersifat jujur, maksudnya guru harus bersifat jujur dalam segala hal, baik itu perkataan maupun perbuatan terhadap anak didiknya, sehingga anak didik dapat mencontoh perbuatannya.

3. Guru harus bertanggung jawab, maksudnya guru harus bertanggung jawab terhadap tugasnya sebagai pendidik.

4. Guru harus bersifat sabar dan rela berkorban, maksudnya sifat sabar harus dimiliki oleh seorang guru, baik di dalam melaksanakan tugasnya atau dalam menanti hasil jerih payahnya, jika mau berhasil dalam mendidik.

5. Guru harus memiliki pengetahuan yang luas, maksudnya sebagai guru yang baik harus senantiasa membaca buku-buku pengetahuan supaya tidak ketinggalan zaman.(Hamdani Ihsan, A. Fuad Hasan, 1998, p.106109)

\section{Tugas-Tugas Seorang Guru}

Agar guru dapat berfungsi sebagai perantara yang baik, maka guru harus dapat melaksanakan tugas dengan baik pula. Tugas seorang guru itu dapat dikelompokkan dalam:

a. Guru sebagai pengajar, adalah lebih menekankan kepada tugas dalam merencanakan dan melaksanakan pengajaran. Dalam tugas ini guru dituntut memiliki seperangkat pengetahuan dan ketrampilan teknis mengajar, disamping menguasai ilmu atau bahan yang akan diajarkannya.

b. Guru sebagai pembimbing, adalah memberi tekanan kepada tugas, memberikan bantuan kepada siswa dalam memecahkan masalah yang dihadapinya. Tugas ini merupakan aspek mendidik sebab tidak hanya berkenaan dengan penyampaian ilmu pengetahuan tetapi juga menyangkut pengembangan kepribadian dan pembentukan nilai-nilai para siswa.

c. Guru sebagai administrator kelas, adalah pada hakikatnya merupakan jalinan antara ketatalaksanaan bidang pengajaran dan keterlaksanaan pada umumnya. Namun demikian, ketatalaksanaan bidang pengajaran lebih menonjol dan lebih diutamakan bagi profesi guru.(Nana Sudjana, 1989, p.15)

\section{Pengertian Disiplin Kelas}

Disiplin merupakan suatu sikap jiwa yang harus dimiliki oleh setiap manusia dalam menjalankan tugasnya agar dapat berjalan dengan baik, lancar, tertib, dan teratur. Jiwa disiplin dan tanggung jawab haruslah ditanamkan saat menjalankan tugas, kapan dan dimanapun mereka berada.

Sedangkan pengertian kelas diuraikan oleh Nawawi yaitu "Suatu masyarakat kecil yang merupakan bagian dari masyarakat sekolah, yang sebagai suatu kesatuan diorganisir menjadi unit kerja yang secara dinamis menyelenggarakan kegiatan-kegiatan belajar mengajar yang kreatif untuk mencapai suatu tujuan.”(Akhyak, 2003, p.279)

Jadi yang dimaksud dengan disiplin kelas adalah ketertiban atau aturan yang diakukan oleh subyek pelaksana pendidikan atau pembimbing bagi anak didik di dalam kelas dengan jalan menaati peraturan-peraturan yang telah 
ditetapkan atas dasar kesenangan dan kesadaran hati demi mencapai suatu tujuan bersama.

\section{Faktor-Faktor Yang Memengaruhi Disiplin Kelas}

Dalam usaha membina dan meningkatkan kedisiplinan dalam lingkungan sekolah dan masyarakat pada umumnya, maka perlu diperhatikan faktor-faktor yang memengaruhi terhadap kedisiplinan seseorang, supaya kedisiplinan tersebut dapat terwujud di dalam kelas.

Menurut Sondang P. Siagian, faktor-faktor yang membentuk perilaku dan termasuk di dalamnya perilaku berdisiplin adalah sebagai berikut:

a. Faktor genetik, adalah segala hal yang oleh seseorang dibawa sejak lahir dan bahkan pula merupakan warisan dari kedua orang tuanya.

b. Faktor lingkungan, adalah merupakan peranan yang sangat penting terhadap kedisiplinan seseorang, karena perkembangan kepribadian seseorang itu selain dipengaruhi oleh sifat pembawaan, juga dipengaruhi oleh situasi dan kondisi dimana dia berada. Lingkungan dapat memberikan peranan positif maupun negatif terhadap perkembangan kepribadian seseorang.

c. Faktor pendidikan, adalah usaha sadar dan sistematis yang berlangsung seumur hidup dalam rangka mengalihkan perhatian oleh seseorang kepada orang lain.(Sondang P Siagian, 1993, p.54)

Disamping kondisi ruang kelas yang dapat memengaruhi keefektifan pengajaran dan juga perilaku-perilaku siswa itu sendiri baik secara individual maupun kelompok. Kadang-kadang juga muncul dari pihak guru, namun guru yang bersangkutan tidak menyadarinya bahkan mungkin menutupinya.

Adapun masalah-maslah yang bersifat individu adalah:

a. Tingkah laku untuk menarik perhatian orang lain, yaitu siswa yang mempunyai perasaan ingin diperhatikan, berusaha mencari kesempatan pada waktu yang tepat untuk melakukan perbuatan yang dikiranya dapat menarik perhatian orang lain.

b. Tingkah laku untuk menguasai orang lain, tingkah laku ini ada yang bersifat aktif dan ada pula yang bersifat pasif.

c. Peragaan ketidakmampuan, siswa yang termasuk kategori ini biasanya sangat apatis (masa bodoh) terhadap pekerjaan apapun.

Sedangkan masalah-masalah yang bersifat kelompok dikategorikan sebagai berikut:

a. Kelas kurang kohesif (akrab), yaitu hubungan antara siswa kurang harmonis, sehingga muncul beberapa kelompok yang tidak bersahabat. Persaingan yang tidak sehat diantara kelompok dapat menimbulkan keonaran

b. Kesebalan terhadap norma-norma yang telah disepakati sebelumnya yaitu tingkah laku yang secara sengaja dilakukan oleh siswa untuk melanggar norma-norma yang telah disepakati sebelumnya dan apabila berhasil mereka merasa puas dan tidak memerdulikan orang lain yang merasa terganggu.

c. Kelas kurang mampu menyesuaikan dengan situasi yang baru, yaitu jika siswa sudah tebiasa belajar dalam kondisi tertentu, maka apabila situasi 
tersebut diubah, siswa sulit menyesuaikan. Akibatnya motivasi dan kegairahan belajar berkurang, bahkan cenderung untuk menolak sama sekali.(Sudirman N. Dkk, 1992, p.322)

Dari poin-poin tersebut diatas, dapat disimpulkan bahwa faktor yang memengaruhi disiplin kelas adalah:

a. Faktor intern yaitu faktor yang timbul dari diri individu itu sendiri. Dalam hal ini pribadi guru dan siswa.

b. Faktor ekstern yaitu faktor yang timbul dari dukungan masyarakat/situasi dan kondisi sekolah.

\section{Usaha-Usaha Untuk Menyiptakan Disiplin Kelas}

Menyiptakan disiplin dalam kelas tidaklah mudah bagi guru, sebab diperlukan usaha-usaha dari para guru itu sendiri. Ada beberapa pendekatan yang dapat digunakan dalam pembinaan disiplin kelas. Dalam hal ini sebagai alternatif pertimbangan dalam menyiptakan disiplin kelas yang efektif, yaitu:

\section{a. Pendekatan Menejerial (Kepemimpinan)}

Dalam pendekatan ini dapat dibedakan:

1. Kontrol otoriter yaitu dalam menegakkan disiplin guru harus bersikap keras, kalau perlu dengan hukuman yang berat. Menurut konsep ini, disiplin kelas yang baik adalah apabila siswa duduk, diam, dan mendengarkan perkataan atau penjelasan dari guru.

2. Kebebasan liberal yaitu siswa diberi kebebasan penuh untuk melakukan kegiatan apa saja sesuai dengan tingkat perkembangannya. Dengan cara ini aktivitas dan kreativitas anak akan berkembang sesuai dengan kemampuannya. Akan tetapi, pemberian kebebasan yang salah digunakan akan berakibat kekacauan di dalam kelas.

3. Kebebasan terbimbing yaitu merupakan perpaduan antara kontrol otoriter dan kebebasan liberal, maksudnya siswa diberi kebebasan untuk melakukan aktivitas namun terbimbing atau terkontrol. Disiplin kelas yang baik menurut konsep ini lebih ditekankan kepada kesadaran dan pengendalian diri sendiri.(Tim Dosen Jurusan Administrasi Pendidikan FIP IKIP Malang, 1989, p.109-110)

\section{b. Pendekatan Psikologis}

Pendekatan yang dimaksud dalam hal ini menyakup antara lain:

1. Pendekatan modifikasi tingkah laku, maksudnya semua tingkah laku yang baik atau yang kurang baik merupakan hasil proses belajar. Ada sejumlah kecil proses psikologis penting yang dapat digunakan untuk menjelaskan terjadinya proses belajar yang dimaksud, yaitu penguatan positif seperti; hadiah, ganjaran, pujian, dan lainnya, juga penguatan negatif seperti; hukuman, ancaman, dan penghapusan hak.

2. Pendekatan iklim sosio-emosional, ini berlandaskan psikologis klinis dan konseling yang memradugakan proses belajar mengajar yang efektif memersyaratkan keadaan sosio-emosional yang baik, dalam arti antara hubungan guru dan siswa juga antara siswa dan siswa. Guru merupakan unsur tepenting bagi terbentuknya sosio-emosional yang baik. Guru juga harus bisa bersikap tulus dihadapan siswa, menerima 
dan menghargai siswa sebagai manusia, dan mengerti siswa dari sudut pandangan siswa sendiri.

3. Pendekatan proses kelompok, yang menjadi anggapan dasar dari pendekatan ini dalah pengalaman belajar sekolah berlangsung dalam kontek kelompok sosial dan tugas pokok guru yang terutama adalah membina kelompok efektif dan produktif.

4. Pendekatan elektif artinya perpaduan antara ketiga pendekatan tersebut diatas, maksudnya pendekatan modifikasi tingkah laku dipilih apabila tujuan yang akan dicapai menguatkan tingkah laku siswa yang baik. Pendekatan sosio-emosional digunakan apabila sasaran tindakan pengelolaan meningkatkan hubungan antar pribadi, guru dan siswa, atau siswa dengan siswa. Sedangkan pendekatan proses kelompok bila guru melakukan kegiatan yang produktif.(Sudirman N. dkk, 1992, p.328)

\section{Guru Sebagai Pelaksana Pertama Tata Tertib}

Tata tertib sekolah merupakan peraturan yang harus dipatuhi atau dijalankan oleh setiap orang yang ada dalam lingkungan sekolah, baik ia kepala sekolah, guru, siswa, atau karyawan-karyawannya. Tata tertib sekolah merupakan salah satu aspek di dalam rangka pembinaan disiplin dalam kelas.

Sedangkan definisi tata tertib itu sendiri adalah sederetan peraturanperaturan yang harus ditaati dalam suatu situasi atau dalam suatu kehidupan tertentu.(Amir Daien Indrakusuma,1973, p.143)

Pembinaan disiplin kelas atau penyegahan pelanggaran disiplin biasa dilakukan dengan cara membuat tata tertib kelas kemudian diberikan penghargan bagi setiap siswa yang melakukan kegiatan yang bersifat positif. Tata tertib kelas harus dirumuskan dan disepakati oleh semua siswa di bawah bimbingan seorang guru.

Hubungan antara peranan guru dalam mencipatakan disiplin kelas terhadap peningkatan prestasi siswa sangat erat sekali. Dalam hal ini guru adalah orang yang pertama kali melaksanakan tata tertib yang ada sebelum para peserta didik melaksanakannya. Hal ini bisa menumbuhkan minat para siswa untuk mematuhi dan melaksanakan tata tertib, sebab guru telah memberikan contoh teladan yang baik dalam melaksanakan tata tertib.

\section{Guru Sebagai Pengarah Anak Dalam Mematuhi Tata Tertib Sekolah}

Dalam hal ini guru bukan hanya sebagai contoh teladan yang baik saja di dalam mematuhi tata tertib sekolah, tetapi harus bisa dan mampu mengarahkan anak di dalam mematuhi tata tertib yang telah ditetapkan, dalam arti lain peranan guru di sini adalah sebagai pengarah.

Mengarahkan anak untuk mematuhi tata tertib sekolah bagi guru bukanlah pekerjaan yang ringan tetapi sangat berat karena diperlukan ketelatenan dan kesabaran. Banyak guru yang gagal di dalam mengarahkan anak untuk mematuhi tata tertib sekolah disebabkan guru tidak telaten atau tidak sabar. Oleh karena itu sifat telaten dan sabar sangat mutlak diperlukan bagi seorang guru. Seumpama ada siswa yang sulit untuk diarahkan, meskipun sudah diberikan contoh yang baik tetapi masih sulit untuk diajak berdisiplin, maka disinilah peranan guru untuk menyadarkannya. 
Sehubungan dengan hal tersebut di atas, Amir Daien Indrakusuma mengatakan, "disamping adanya pembiasaan yang disertai dengan contoh dan teladan, maka kepada anak yang sudah mulai kritis pikirannya itu sedikit demi sedikit harus diberikan penjelasan-penjelasan tentang pentingnya peraturanperaturan itu diadakan. Anak lambat laun menyadari nilai dan fungsi dari peraturan-peraturan itu, dan apabila kesadaran itu telah timbul, ini berarti pada anak telah mulai tumbuh disiplin diri sendiri." (Amir Daien Indrakusuma, 1973, p.146)

Mengarahkan anak untuk mematuhi tata tertib sekolah bukan hanya dilakukan satu atau dua kali saja, tetapi harus kontinyu. Mengarahkan dalam hal ini dapat dilakukan dengan cara;

a. Guru harus memberikan motivasi dan dorongan-dorongan kepada anak $\mathrm{didik} / \mathrm{siswa}$ untuk senantiasa mematuhi tata tertib sekolah.

b. Guru harus memberikan penghargaan atau pujian kepada siswa yang patuh dan disiplin di dalam mematuhi tata tertib.

c. Siswa yang tidak mematuhi tata tertib sekolah hendaknya diberi arahan dan pemberitahuan tentang manfaatnya tata tertib sekolah, sekiranya siswa tetap melanggar, maka harus diberi hukuman yang sesuai dengan kesalahannya, sehingga menjadi pelajaran baginya.

\section{Guru Sebagai Pengawas Siswa Dalam Melaksanakan Segala Aturan Sekolah}

Pada bagian ini, peranan guru selanjutnya adalah sebagai pengawas bagi anak didiknya dalam melaksanakan segala aturan sekolah, dalam arti orang yang mengawasi segala aturan yang ada di sekolah.

Berbicara masalah mengawasi, berarti melihat dan memerhatikan tingkah laku orang. Dalam hal ini melihat dan memerhatikan tingkah laku siswa dalam melaksanakan segala aturan sekolah demi tercapainya pendidikan yang optimal.

Adapun tujuan pengawasan menurut Amir Daien Indrakusuma adalah untuk menjaga atau mencegah agar tidak terjadi sesuatu yang tidak diinginkan. Dan untuk memerkuat kedudukan dari pengawasan, maka dapat diikuti adanya hukuman-hukuman bilamana perlu. Bagi anak-anak yang sudah besar, pengawasan hendaknya diperlonggar, sehingga pengawasan di sisini bersifat "tut wuri handayani”.(Amir Daien Indrakusuma, 1973, p.174)

Sebelum guru mengawasi siswa dalam mematuhi tata tertib sekolah, maka ia harus melihat dirinya sendiri apakah dirinya sudah disiplin atau sebaliknya. Anak akan patuh kepada guru yang senantiasa menampakkan kedisiplinan dalam melaksanakan tugasnya dan begitu pula sebaliknya. Oleh karena itu, guru harus menampakkan kedisiplinannya di depan siswa-siswanya agar ia disegani dan dihormati, dengan begitu akan memberikan dampak yang positif kepada siswa dan membawa suasana kegiatan belajar mengajar di kelas akan tenang dan juga aktif.

\section{Guru Memberikan Penghargaan dan Hukuman Kepada Para Siswa}

Peranan guru selanjutnya adalah memberikan penghargaan dan hukuman kepada para siswa. Penghargaan diberikan kepada para siswa yang tertib dan taat dalam melaksankan tata tertib, sedangkan hukuman diberikan kepada siswa yang melanggar tata tertib. 
Menurut Amir Daien Indrakusuma bahwa penghargaan dan hukuman merupakan alat pendidikan represif atau alat pendidikan korektif yang bertujuan untuk menyadarkan anak kembali kepada hal-hal yang benar, yang baik, yang tertib. Kalau penghargaan merupakan alat represif yang bersifat menyenangkan sedangkan hukuman merupakan alat represif yang bersifat tidak menyenangkan. (Amir Daien Indrakusuma, 1973, p.150)

Dengan penghargaan bisa menjadikan anak lebih giat lagi dalam belajar, mematuhi tata tertib, disiplin. Sedangkan dengan hukuman bisa membuat anak jera sehingga ia akan berusaha untuk tidak memperoleh hukuman lagi dengan selalu mentaati tata tertib dan tugas-tugas belajarnya.

\section{METODE PENELITIAN}

\section{Populasi}

Populasi adalah seluruh penduduk yang dimaksudkan untuk diselidiki. Populasi dibatasi sebagai sejumlah penduduk atau individu yang paling sedikit mempunyai satu sifat yang sama.(Sutresno Hadi, 1987, p.220)

Adapun yang menjadi populasi dalam penelitian ini adalah 252 siswa MI Muhammadiyah 11 Blimbing Paciran Lamongan.

\section{Sampel}

Sampel adalah sebagian atau wakil populasi yang diteliti.(Suharsimi Arikunto, 1993, p.102) Dalam definisi yang lain disebutkan sampel adalah sebagian individu yang diteliti.(Sumardi Suryabrata, 2005, p.35)

Pada penelitian ini penulis hanya mengambil sampel dari siswa kelas V saja Tahun Pelajaran 2014/2015 yang berjumlah 30 siswa. Hal ini penulis lakukan karena penulis tidak mampu menjangkau seluruh populasi yang ada, disamping juga karena keterbatasan waktu dan tenaga.

\section{Sumber Data}

Sumber data adalah subyek dari mana data dapat diperoleh.(Suharsimi Arikunto, 1993, p.102) Adapun sumber data dalam penelitian ini terdiri dari :

a. Sumber data manusia yang meliputi kepala sekolah, guru-guru, karyawan, dan para siswa itu sendiri.

b. Sumber data non-manusia yang meliputi buku literature dan dokumendokumen yang berhubungan dengan penelitian ini.

\section{Metode Pengumpulan Data}

Agar dalam penelitian ini mendapatkan data yang valid, maka digunakan metode pengumpulan data dengan data yang diperlukan. Metode-metode tersebut antara lain;

1. Observasi

Observasi yaitu memerhatikan sesuatu dengan menggunakan mata atau di dalam pengertian psikologi disebutkan bahwa observasi adalah pengamatan yang meliputi kegiatan pemusatan perhatian terhadap sesuatu obyek dengan menggunakan seluruh alat indra.(Suharsimi Arikunto, 1993, p.128)

Dengan metode ini, peneliti mengadakan pengamatan langsung terhadap obyek penelitian tentang lokasi, sarana pendidikan, kegiatan guru dan siswa dalam proses belajar mengajar. 


\section{Interview}

Interview sering juga disebut dengan wawancara atau kuisioner lisan adalah sebuah dialog yang dilakukan oleh pewawancara untuk memeroleh informasi dari terwawancara.(Suharsimi Arikunto, 1993, p.126)

Dalam menggunakan metode interview dimaksudkan untuk memeroleh data mengenai lingkungan sekolah, peranan guru dalam menyiptakan disiplin kelas serta prestasi belajar siswa.

3. Angket (Kuisioner)

Angket (kuisioner) adalah sejumlah pertanyaan tertulis yang digunakan untuk memeroleh informasi dari responden dalam arti laporan tentang pribadinya, atau hal-hal yang ia ketahui.(Suharsimi Arikunto, 1993, p.124)

Dalam hal ini sumber data yang diberi angket sebanyak 30 siswa. Angket ini dimaksudkan untuk memeroleh data (informasi) tentang kemampuan guru dalam menciptakan disiplin kelas, dalam hal ini guru sebagai pelaksana pertama dalam melaksanakan disiplin kelas, mengawasi, mengarahkan siswa dalam menerapkan disiplin kelas serta memberikan penghargaan atau hukuman.

Angket yang digunakan adalah angket langsung tertutup, yaitu angket yang diberikan langsung kepada responden serta jawaban yang diberikan sudah disediakan oleh peneliti, sehingga responden tinggal memilih.

4. Dokumentasi

Dokumentasi adalah suatu cara untuk mengumpulkan data berdasarkan dokumen yang berupa tulisan maupun laporan yang memuat tentang gejala seperti jumlah guru, keadaan sekolah, jumlah murid, catatan investasi, legger, agenda.(Suharsimi Arikunto, 1993, p.131)

Metode ini dipergunakan untuk mencari data yang sifatnya paten. Misalnya mengenai sejarah berdirinya sekolah, struktur organisasi, jumlah guru serta jabatannya, jumlah siswa, dan yang paling penting adalah tentang prestasi belajar siswa yaitu berupa nilai (IP) yang diambil dari legger.

\section{Teknik Analisis Data}

Teknik analisis data adalah cara-cara yang digunakan untuk menganalisis data dari hasil penelitian. Dalam penelitian ini penulis menggunakan analisis diskriptif dan analisis statistik. Analisis diskriptif penulis gunakan untuk menuturkan, menafsirkan serta menguraikan data yang berkaitan dengan peranan guru dalam menciptakan disiplin kelas terhadap peningkatan prestasi belajar siswa. Sedangkan analisis statistik yang dalam hal ini penulis menggunakan analisis korelasi product moment mempunyai tujuan untuk mengetahui hubungan antara variabel yang satu dengan variabel yang lain. (Anas Sudijono, 2005, p.170) Kedua variabel yang dimaksud adalah peranan guru dalam menciptakan disiplin dan prestasi belajar siswa. 
Dalam menganalisis data tentang korelasi peranan guru dalam menciptakan disiplin kelas terhadap peningkatan prestasi belajar siswa, penulis menggunakan analisis product moment dengan rumus angka sebagai berikut:

$r_{x y}=\frac{\Sigma X Y-\frac{(\Sigma X)(\Sigma Y)}{N}}{\sqrt{\left\{\Sigma X^{2}-\frac{(\Sigma X)^{2}}{N}\right\}\left\{\sum Y^{2}-\frac{\left(\sum Y\right)^{2}}{N}\right\}}}$

$\mathrm{r}_{\mathrm{xy}} \quad$ : Koefisien korelasi $\mathrm{X}$ dan $\mathrm{Y}$

$\sum X \quad$ : Jumlah nilai variabel $\mathrm{X}$

$\sum \mathrm{Y}$ : Jumlah nilai Variabel Y

N : Jumlah subyek yang diselidiki. (Sukardi, 2003:90).

Keterangan:

1. Data $X$ adalah skor yang diperoleh dari angket tentang peranan guru dalam menyiptakan disiplin kelas.

2. Data Y adalah skor yang diperoleh dari prestasi belajar siswa, dalam hal ini nilai rata-rata (IP).

Dengan menggunakan rumus diatas, maka akan diperoleh nilai korelasi $\left(\mathrm{r}_{\mathrm{xy}}\right)$. Nilai " $\mathrm{r}$ " ini kemudian dikonsultasikan dengan nilai " $\mathrm{r}$ " product moment dalam tabel, dan selanjutnya akan diketahui, diterima atau ditolaknya hipotesis yang penulis ajukan. Untuk pengetesan hasil ini digunakan taraf signifikan $1 \%$ dan $5 \%$. Jika nilai yang kita peroleh sama dengan atau lebih besar dari pada " $r$ " dalam tabel, maka nilai yang kita peroleh itu berarti signifikan. Dalam nilai " $r$ " yang signifikan itu berarti hipotesa nol (nihil) di tolak, dan sebaliknya apabila " $\mathrm{r}$ " yang diperoleh berada di bawah nilai " $\mathrm{r}$ " pada tabel, berarti tidak signifikan dan hipotesis nol (nihil) di terima.(Suharsimi Arikunto, 1993, p.223)

\section{Paparan Dan Pembahasan Data Hasil Penelitian}

Dari data yang penulis peroleh menyebutkan, bahwa ada empat kriteria yang dilakukan oleh guru dalam rangka menciptakan disiplin kelas, diantaranya :

\section{Guru sebagai pelaksana pertama tata tertib}

Tata tertib sekolah merupakan peraturan yang harus dipatuhi atau dijalankan oleh setiap orang yang ada dalam lingkungan sekolah, baik ia kepala sekolah, guru, siswa, atau karyawan-karyawannya. Tata tertib sekolah merupakan salah satu aspek di dalam rangka pembinaan disiplin dalam kelas.

Hubungan antara peranan guru dalam menciptakan disiplin kelas terhadap peningkatan prestasi siswa sangat erat sekali. Dalam hal ini guru adalah orang yang pertama kali melaksanakan tata tertib yang ada sebelum para peserta didik melaksanakannya. Hal ini bisa menumbuhkan minat para siswa untuk mematuhi dan melaksanakan tata tertib, sebab guru telah memberikan contoh teladan yang baik dalam melaksanakan tata tertib. 


\section{Guru sebagai pengarah anak dalam mematuhi tata tertib sekolah}

Dalam hal ini guru bukan hanya sebagai contoh teladan yang baik saja di dalam mematuhi tata tertib sekolah, tetapi harus bisa dan mampu mengarahkan anak di dalam mematuhi tata tertib yang telah ditetapkan, dalam arti lain peranan guru di sini adalah sebagai pengarah.

Disamping anak diberikan contoh yang baik, maka anak juga harus diarahkan supaya bisa meneladani dan menyontoh perbuatan baik yang dilakukan oleh para guru. Hal ini bisa menumbuhkan sifat dan minat para siswa untuk melaksanakan disiplin karena selalu diberikan pengarahan oleh guru dalam melaksanakan perbuatan baik serta ada perhatin dari para guru. Selain itu juga siswa harus selalu diberikan motivasi supaya bisa menaati tata tertib sekolah.

\section{Guru sebagai pengawas siswa dalam melaksanakan segala aturan sekolah}

Pada bagian ini, peranan guru selanjutnya adalah sebagai pengawas bagi anak didiknya dalam melaksanakan segala aturan sekolah, dalam arti orang yang mengawasi segala aturan yang ada di sekolah.

Sebelum guru mengawasi siswa dalam mematuhi tata tertib sekolah, maka ia harus instrospeksi diri apakah dirinya sudah disiplin atau sebaliknya. Anak akan patuh kepada guru yang senantiasa menampakkan kedisiplinan dalam melaksanakan tugasnya dan begitu pula sebaliknya. Oleh karena itu, guru harus menampakkan kedisiplinannya di depan siswa-siswanya agar ia disegani dan dihormati, dengan begitu akan memberikan dampak yang positif kepada siswa dan membawa suasana kegiatan belajar mengajar di kelas akan tenang dan juga aktif.

Mengawasi siswa dalam melaksanakan segala aturan sekolah itu sangat perlu sekali, karena hal ini sangat penting demi menyiptakan dispilin dalam kelas. Dan hal ini juga bisa menunjang peningkatan prestasi belajar siswa.

\section{Guru memberikan penghargaan dan hukuman kepada para siswa.}

Peranan guru selanjutnya adalah memberikan penghargaan dan hukuman kepada para siswa. Penghargaan diberikan kepada para siswa yang tertib dan taat dalam melaksankan tata tertib, sedangkan hukuman diberikan kepada siswa yang melanggar tata tertib.

Dengan penghargaan bisa menjadikan anak lebih giat lagi dalam belajar, mematuhi tata tertib, disiplin. Sedangkan dengan hukuman bisa membuat anak jera sehingga ia akan berusaha untuk tidak memperoleh hukuman lagi dengan selalu mentaati tata tertib dan tugas-tugas belajarnya.

Peranan ini sangat penting sekali, karena peranan ini merupakan sebuah evaluasi dari para guru untuk melihat dan mengamati sejauh mana prilaku disiplin siswa di dalam kelas. Dan peranan guru ini juga bisa meningkatkan prestasi belajar siswa, karena mereka akan termotivasi untuk terus belajar dan tidak melanggar tata terib yang ada.

Dari beberapa peranan guru diatas, dapat disimpulkan bahwa ada perkembangan yang cukup signifikan yang muncul dari diri para siswa baik itu masalah disiplin, perilaku dan juga prestasi belajarnya. Hal ini tidak terlepas dari peranan para guru yang begitu baik dan semangat dalam menciptakan disiplin dalam kelas. 
Sedangkan untuk data statistiknya mengenai peranan guru dalam menyiptakan disiplin kelas terhadap peningkatan prestasi belajar siswa penulis menggunakan rumus "korelasi product moment" yang bertujuan untuk mengetahui ada tidaknya hubungan antara dua variabel tersebut diatas, dan rumus tersebut terformulasikan sebagai berikut :

$$
r_{x y}=\frac{\Sigma X Y-\frac{(\Sigma X)(\Sigma Y)}{N}}{\sqrt{\left\{\Sigma X^{2}-\frac{(\Sigma X)^{2}}{N}\right\}\left\{\sum Y^{2}-\frac{\left(\sum Y\right)^{2}}{N}\right\}}}
$$

Setelah harga-harga atau nilai tersebut diperoleh, kemudian dimasukan kedalam rumus kolerasi product moment adalah sebagai berikut :

$$
\begin{aligned}
& r_{x y}=\frac{\sum X Y-\frac{(\Sigma X)(\Sigma Y)}{N}}{\sqrt{\left\{\Sigma X^{2}-\frac{(\Sigma X)^{2}}{N}\right\}\left\{\sum Y^{2}-\frac{\left(\sum Y\right)^{2}}{N}\right\}}} \\
& r_{x y}=\frac{15669,85-\frac{(2097)(223,79)}{30}}{\sqrt{\left\{146803-\frac{(2097)^{2}}{30}\right\}\left\{167608-\frac{(223,79)^{2}}{30}\right\}}} \\
& r_{x y}=\frac{1566985-15642,921}{\sqrt{\{146803-1465803\}\{1676,08-1669,40\}}} \\
& r_{x y}=\frac{26,929}{\sqrt{1487,636}} \\
& r_{x y}=\frac{26,929}{\sqrt{(2227)(6,68)}} \\
& r_{x y}=\frac{26,929}{38,569} \\
& =0,698
\end{aligned}
$$

Setelah kita ketahui harga/nilai kolerasi tersebut, selanjutnya dikonsultasikan dengan " $r$ " tabel pada taraf signifikan 1\% dan taraf signifikan 5\%, dengan melihat $\mathrm{N}=30$. Dalam tabel " $\mathrm{r}$ " pada taraf signifikan $1 \%$ tercantum bilangan 0,449 sedangkan pada taraf signifikan $5 \%$ tercantum bilangan 0,349 . Ini berarti " $r$ " yang kita peroleh lebih besar dari " $r$ " tabel dengan perbandingan sebagai berikut :

$0,698>0,449$ dan $0,698>0,349$

Karena " $r$ " yang diperoleh berada jauh di atas batas signifikansinya, maka nialai " $r$ " yang diperoleh merupakan korelasi signifikan. Dengan demikian kita menolak hipotesis nihil yang berbunyi "bahwa peranan guru dalam menyiptakan disiplin kelas tidak berpengaruh terhadap peningkatan prestasi belajar siswa", dan menerima hipotesis kerja yang berbunyi "peranan guru dalam menyiptakan disiplin kelas ada pengaruh terhadap peningkatan prestasi belajar siswa.

Selanjutnya untuk mengukur adakah korelasinya antara peranan guru dalam menyiptakan disiplin kelas terhadap peningkatan prestasi belajar siswa di 
MI Muhammadiyah 11 Blimbing, maka nilai "r" yang kita peroleh dikonsultasikan dengan tabel interprestasi nilai "r" yang telah ditetapkan, dalam hal ini penulis menggunakan pedoman sebagai berikut :

\begin{tabular}{|l|l|}
\hline $\begin{array}{l}\text { Besarnya } \\
\text { nilai "r" }\end{array}$ & Interpretasi \\
\hline $\begin{array}{l}\text { Antara 0,800 } \\
\text { s/d 1,00 }\end{array}$ & Tinggi \\
\hline $\begin{array}{l}\text { Antara 0,600 } \\
\text { s/d 0,800 }\end{array}$ & Cukup \\
\hline $\begin{array}{l}\text { Antara 0,400 } \\
\text { s/d 0,600 }\end{array}$ & Agak Rendah \\
\hline $\begin{array}{l}\text { Antara 0,200 } \\
\text { s/d 0,400 }\end{array}$ & Rendah \\
\hline $\begin{array}{l}\text { Antara 0.000 } \\
\text { s/d 0,200 }\end{array}$ & $\begin{array}{l}\text { Sangat } \\
\text { Rendah (tidak } \\
\text { berkorelasi) }\end{array}$ \\
\hline
\end{tabular}

Dari kreteria yang telah ditetapkan, diketahui bahwa nilai "r" 0,698 berada diantara $0,600-0,800$, yang berada pada taraf cukup.

Berdasarkan analisis diatas, maka dapat diambil kesimpulan bahwa :

1. Ada korelasi antara variabel $\mathrm{X}$ dan $\mathrm{Y}$.

2. Terdapat korelasi yang signifikan antara variabel $\mathrm{X}$ dan variabel $\mathrm{Y}$.

3. Korelasi antara variabel $\mathrm{X}$ dan varabel Y termasuk dalam kategori cukup.

4. Harga korelasi signifikan, dalam hal ini hasil analisis lebih besar dari nilai " $\mathrm{r}$ " dalam tabel, baik pada taraf signifikan 1\% maupun taraf signifikan 5\% dengan harga $\mathrm{N}=30$, maka harga untuk " $r$ " pada taraf signifikan $1 \%$ diperoleh 0,449 , sedangkan pada taraf $5 \%$ diperoleh 0,349 , adapun hasil dari analisis adalah sebesar 0,698.

Berdasarkan hasil kesimpulan diatas, maka dapat ditetapkan bahwa "semakin tinggi peranan guru dalam menciptakan kelas, maka semakin tinggi pula prestasi belajar siswa di MI Muhammadiyah 11 Blimbing Paciran Lamongan.

\section{Kesimpulan dan Saran}

\section{Kesimpulan}

Sebagai penutup dari penulisan skripsi ini, maka penulis dapat memberikan kesimpulan sebagai berikut :

1. Bahwa peranan guru dalam menciptakan disiplin kelas adalah dengan cara sebagai berikut, antara lain: guru sebagai pelaksana pertama dalam mematuhi tata tertib sekolah, guru sebagai pengarah siswa dalam mematuhi tata tertib sekolah, guru sebagai pengawas siswa dalam melaksanakan segala aturan sekolah, dan guru memberikan hadiah dan hukuman kepada para siswa.

2. Prestasi belajar siswa di MI Muhammadiyah 11 Blimbing, tahun 2014/2015 berdasarkan data yang penulis peroleh dari dokumen sekolah menunjukkan nilai yang cukup.

3. Ada korelasi antara peranan guru dalam menciptakan disiplin kelas terhadap peningkatan prestasi belajar siswa di MI Muhammadiyah 11 
Blimbing, dan korelasi yang ditunjukkan tergolong korelasi yang cukup dengan hasil nilai 0,698 .

\section{Saran-saran}

Adapun saran-saran yang dapat dijadikan input dalam rangka menyiptakan disiplin di dalam kelas baik bagi guru ,maupun bagi siswa sendiri sehubungan dengan peningkatan prestasi belajar adalah sebagai berikut :

1. Guru hendaknya memberikan motivasi kepada siswanya tentang manfaat disiplin kelas.

2. Guru hendaknya memberikan tauladan dan juga bimbingan disiplin yang baik agar siswa dapat menyontohnya.

3. Hendaknya para siswa dapat menyadari betapa pentingnya prilaku disiplin, serta juga keikhlasan dan kesungguhan dalam menaati segala peraturan sekolah.

\section{Daftar Rujukan}

Ahmadi, Abu dan Nur Uhbiyati. Ilmu Pendidikan. Jakarta. PT Rineka Cipta, 2001.

Akhyak (ed). Meniti Jalan Pendidikan Islam. Jogjakarta : Pustaka Pelajar, 2003.

Arikunto, Suharsimi. Prosedur Penelitian Suatu Pendekatan Praktek. Jakarta: PT Rineka Cipta, 1993.

Daien Indrakusuma, Amir. Pengantar Ilmu Pendidikan. Malang : FIP IKIP Malang, 1973.

Djamaroh, Syaiful Bakri. Prestasi Belajar dan Kopetensi Guru. Surabaya : Usaha Nasional, 1989.

Hadi, Sutresno. Statistik 2. Jogyakarta: Fak. Psikologi UGM, 1987.

Hamalik, Oemar. Perencanaan Pengajaran Berdasarkan Pendekatan Sistem. Jakarta: Bumi Aksara, 2008.

Ihsan, Hamdani dan A. Fuad Hasan. Filasafat Pendidikan Islam. Bandung : Pustaka Setia, 1998.

Marimba. Ahmad D. Pengantar Filsafat Pendidikan Islam. Bandung: PT Alma'arif, 1981.

N, Sudirman dkk. Ilmu Pendidikan. Bandung : PT Remaja Rosdakarya, 1992.

Nata, Abudin. Menejemen Pendidikan:Mengatasi Kelemahan Pendidikan Islam di Indonesia. Bogor: Kencana. 2003.

Purwanto, Ngalim. Ilmu Pendidikan Teoritis dan Praktis. Bandung : PT Remaja Rosdakarya, 1995.

Siagian, Sondang P. Organisasi Kepemimpinan dan Prilaku Administrasi. Jakarta: Haji Masagung, 1993.

Slameto. Belajar dan Faktor-Faktor Yang Mempengaruhinya. Jakarta: Rineka Cipta, 2003.

Sudijono, Anas. Pengantar Evaluasi Pendidikan. Jakarta: PT Raja Grafindo Persada, 2005.

Sudjana, Nana. Cara Belajar Siswa Akjtif Dalam Proses Belajar Mengajar. Bandung: Sinar Baru Algensindo, 1989.

--------- Dasar-Dasar Proses Belajar Mengajar. Bandung: Sinar Baru, 1991.

Suryabrata, Sumardi. Metodologi Penelitian. Jakarta: PT Raja Grafindo Persada, 2005. 
Sukardi, Metodoogi Penelitian pendidikan: Kompetensi dan Prakteknya. Jakarta: PT. Bumi Aksara, 2003.

Syah, Muhibbin. Psikologi Belajar. Jakarta : Logos wacana Ilmu, 2001.

Tim Bahasa Pustaka Agung Harapan, Kamus Lengkap Bahasa indonesia Modern. Surabaya: Pustaka Agung Harapan, 2000.

Tim Dosen Jurusan Administrasi Pendidikan FIP IKIP Malang. Administrasi Pendidikan. Malang: IKIP Malang, 1989.

Undang-Undang Republik Indonesia Nomor 20 Tahun 2003 Tentang Sistem Pendidikan Nasional. Bandung: Citra Umbara, 2003.

Undang-Undang Guru dan Dosen nomor 14 tahun 2005.

Usman, Moh Uzer. Menjadi Guru Profesional. Bandung: PT Remaja Rosdakarya, 2001.

Wijaya, Cece dan A. Tabrani Rusyan. Kemampuan Dasar Guru Dalam Proses Belajar Mengajar. Bandung : PT Remaja Rosdakarya, 1989.

Wawancara dengan Drs. Miftahul Maayis selaku putra Bapak Mas'ud Abdurrohman pendiri MI Muhammadiyah 11 TPAY Blimbing tanggal 24 Maret 2015. 